\title{
Dampak Pembelajaran Dari Masa Pandemi Covid-19 terhadap Motivasi Belajar Siswa SMP di Kota Bukittinggi
}

\author{
Dedi Robandi ${ }^{1 凶}{ }^{\text {, Mudjiran }}{ }^{2}$ \\ Ilmu Pendidikan, Universitas Negeri Padang \\ E-mail: dederobandi1976@gmail.com,mudjiran.unp@gmail.com
}

\begin{abstract}
Abstrak
Pandemi Covid-19 memberikan dampak yang siknifikan baik dalam segi ekonomi maupun pendidikan. Pendidikan secara daring serta bekerja dari rumah untuk para tenaga pendidik ialah pergantian yang wajib dilakukan oleh guru agar dapat tetap melakukan pemebalajaran dan berinteraksi dengan siswa. Pembelajaran dengan jarak jauh mempunyai tujuan supaya kualitas pembelajaran tingkatkan serta relevansi pembelajaran dan tingkatkan pemerataan akses serta ekspansi pembelajaran. Pembelajaran jarak jauh yang diselenggarakan dengan penjaminan mutu yang baik serta cocok dengan kebutuhan pemangku kepentingan ialah salah satu mekanisme ekspansi akses pembelajaran besar. Berdasarkan hasil penelitian diketehui bahawa motivasi belajar siswa pada pembelajaran berbasis daring $11 \%$ siswa berada pada kategori sangat tinggi, 38\% siswa berada pada kategori cukup, $27 \%$ siswa berada pada kategori motivasi sedang dan $24 \%$ siswa berada pada kategori motivasi rendah. Dari hasil ini dapat diketahui bahwa pencapain hasil motivasi belajar belum maksimal, maka diperlukan upaya-upaya untuk meningkatkan motivasi belajar siswa sehingga lebih maksimal.
\end{abstract}

Kata kunci: Daring, Pembelajaran, COVID-19

\begin{abstract}
The Covid-19 pandemic has had a significant impact both in terms of the economy and education. Online education and working from home for educators are compulsory changes that teachers must make in order to continue learning and interacting with students. Distance learning has the goal of increasing the quality of learning and the relevance of learning and increasing equitable access and expansion of learning. Distance learning, which is organized with good quality assurance and is in accordance with the needs of stakeholders, is one of the major mechanisms for expanding access to learning. Based on the results of the study, it was known that student motivation in online-based learning $11 \%$ of students were in the very high category, $38 \%$ of students were in the sufficient category, $27 \%$ of students were in the medium motivation category and $24 \%$ of students were in the low motivation category. From these results it can be seen that the achievement of learning motivation results has not been maximized, so efforts are needed to increase student learning motivation so that it is more optimal.
\end{abstract}

Keywords: Online, Learning, COVID-19

\section{PENDAHULUAN}

Pandemi COVID 19 di Indonesia mulai mewabah semenjak mula maret 2020. Sampai dikala ini kenaikan kasuspun terjalin di segala daerah Indonesia. Badan Nasional Penanggulangan Bencana (BNPB) menghasilkan surat keputusan no $13 \mathrm{~A}$ mengenai penetapan masa darurat akibat virus corona. Bersumber pada penetapan tersebut, Departemen Pembelajaran dan Kebudayaan (Kemendikbud) menghasilkan Surat Edaran dari Menteri Pembelajaran serta Kebudayaan No: 36962/ MPK. A/ HK/ 2020 tertanggal 17 Maret 2020 tentang Pendidikan secara Daring serta Bekerja dari Rumah dalam rangka Penangkalan Penyebaran Corona Virus Disease (COVID- 19). 
Pendidikan ialah inti dari proses pembelajaran. Mutu pembelajaran menggambarkan mutu pendidikan. Kenaikan mutu pembelajaran bisa dicoba lewat kenaikan mutu pembelajaran. Pendidikan secara daring serta bekerja dari rumah untuk para tenaga pendidik ialah pergantian yang wajib dicoba oleh guru buat senantiasa mengajar siswa. Pembelajaran dengan jarak jauh mempunyai tujuan supaya kualitas pembelajaran tingkatkan serta relevansi pembelajaran dan tingkatkan pemerataan akses serta ekspansi pembelajaran. Pembelajaran jarak jauh yang diselenggarakan dengan penjaminan mutu yang baik serta sesuai dengan kebutuhan pemangku kepentingan ialah salah satu mekanisme ekspansi akses pembelajaran sekala besar. Program Belajar Jarak Jauh (PBJJ) ialah alternatif yang digunakan pada masa pandemic covid-19 oleh tiap sekolah buat melakukan proses belajar mengajar meski tidak dengan tatap muka. Pergantian proses belajar dari tatap muka jadi PBJJ ialah sesuatu keputusan yang wajib dicoba oleh sekolah supaya tujuan pembelajaran bisa dilaksanakan secara efisien serta efesien. Sekolah ialah suatu organisasi modern yang wajib menyesuaikan diri dengan pergantian area. Sekolah di tengah pandemi COVID- 19 wajib senantiasa melaksanakan proses belajar mengajar. dengan mengubahnya jadi PBJJ. PBJJ ini jadi tantangan untuk tiap sekolah buat senantiasa mejalankan tujuan pembelajaran.

Pandemi COVID- 19 mengharuskan Sekolah melaksanakan budaya adaptif. Pandemi COVID 19 di Indonesia mulai mewabah semenjak dini maret 2020. Sampai dikala ini kenaikan kasuspun terjalin di segala daerah Indonesia. Tubuh Nasional Penanggulangan Musibah( BNPB) menghasilkan pesan keputusan no $13 \mathrm{~A}$ terpaut penetapan masa darurat akibat virus corona. Penelitian ini diharapkan dapat mengetahui tingkat motivasi belajar siswa SMP Negeri di Kota Bukittinggi.

\section{METODE}

Metode yang digunakan dalam penelitian ini adalah penelitian deskriptif dengan pendekatan kuantitatif yang bertujuan mengungkapkan suatu apa adanya. Menurut Arikunto (2006:12) dengan penelitian kuantitatif, banyak dituntut menggunakan angka, mulai dari pengumpulan data penafsiran terhadap data tersebut, serta penampilan dari hasilnya. Jadi dapat disimpulkan bahwa penelitian deskriptif kuantitatif dalam penelitian ini adalah untuk melihat, meninjau dan menggambarkan dengan angka tentang objek yang diteliti seperti apa adanya dan menarik kesimpulan tentang hal tersebut sesuai fenomena yang tampak pada saat penelitian dilakukan.

Penelitian dilakukan di Sekolah Menengah Pertama se-Kota Bukittinggi yaitu sebanyak 5 sekolah, dilakukan di kelas II yaitu sebanyak tujuh kelas. Penelitian ini berjalan selama dua bulan yaitu dari bulan Oktober-November 2020. Tahap pelaksanaan penelitian didahului dengan perancanagan angket motivasi yang berdasarkan gabungan indikator motivasi belajar yang dikemukakan oleh Uno dan Sardiman yakni (1) Adanya hasrat dan keinginan untuk berhasil; (2) Adanya dorongan dan kebutuhan dalam belajar; (3) Tekun menghadapi tugas; (4) Ulet menghadapi kesulitan; (5)Adanya kegiatan menarik dalam belajar. Kemudian penyebaran angket dan pengumpulan dokumentas hasil belajar siswa.

\section{HASIL DAN PEMBAHASAN}

Tingkat motivasi belajar siswa SMP Negeri di Kota Bukittinggi pada masa pandemic covid-19 secara umum dapat digambarkan pada pada gambar 1. Berdasarkan diagaram gambar 1 diketahui bahwa terdapat $11 \%$ siswa yang memiliki motivasi sangat tinggi, $38 \%$ siswa yang memiliki motivasi tinggi, $27 \%$ siswa yang memiliki motivasi cukup dan $24 \%$ siswa yang memiliki motivasi rendah.

Tranformasi pembelajaran dapat menjadi salah satu kunci perguruan tinggi untuk keluar dari krisis pandemi COVID19 yang berkepanjangan. Pemakaian virtual learning dalam proses pendidikan jarak jauh diyakini dipertimbangkan dalam perhitungan, neurotisisme jadi tidak mempunyai sumbangan terhadap social media fatigue. Hasil riset ini pula menampilkan besarnya sumbangan kelebihan data terhadap social media fatigue 
serta lebih rentannya kelompok siswa laki- laki buat hadapi social media fatigue dikala belajar di rumah sepanjang pandemi COVID- 19

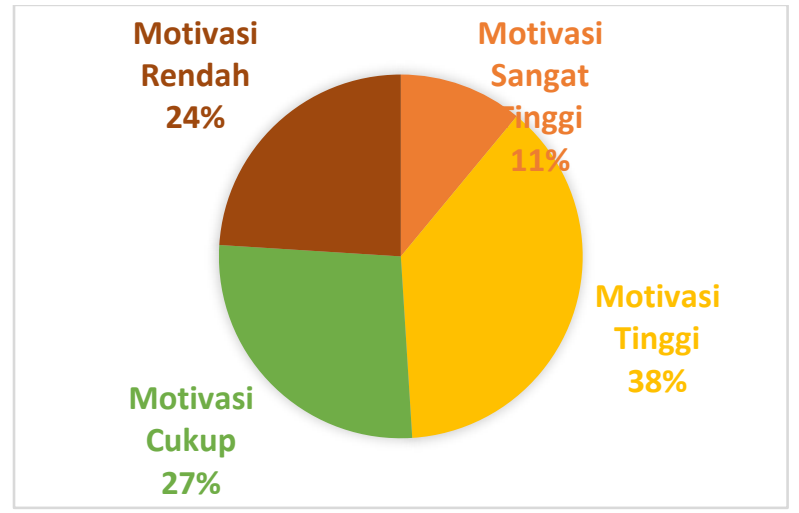

\section{Gambar 1. Diagram Presentasi Motivasi Belajar Siswa SMP Negeri Kota Bukittinggi}

Besarnya beban kognitif serta minimnya keahlian memproses data yang ditengarai jadi pemicu terbentuknya social media fatigue. Pihak- pihak terpaut semacam akademi besar diharapkan bisa mencermati dampak belajar di rumah untuk siswa sepanjang pandemi COVID- 19. Hasil riset menampilkan kalau aspek keterhubungan serta aspek pendidikan pada pendidikan daring memakai whatsapp groupmenurut sudut pandang siswa lebih besar dibanding dengan memakai webinar Zoom. Tidak hanya itu, 98\% siswa lebih memilah memakai whatsapp group buat digunakan dalam pendidikan daring pada masa pandemi COVID- 19. Sarana untuk dapat berbicara secara langsung via dunia maya, serta menjauhi kontak raga supaya menghindari penularan COVID- 19. Interaksi langsung membagikan sentuhan bermakna antara pendidik serta partisipan didik, yang bisa memicu benak, perasaan serta keinginan siswa. Lewat interaksi langsung, pendidik sanggup mewujudkan atmosfer belajar serta proses belajar pendidikan cocok dengan kepribadian serta kebutuhan partisipan didik dan pencapaian tujuan pembelajaran. Lebih dalam lagi, interaksi secara langsung antara pendidik serta partisipan didik sanggup menimbulkan perasaan silih memerlukan, menghargai, kasih sayang, hingga perasaan rindu kala partisipan didik lulus dari mata kuliah yang diampu guru tersebut.

Demi menekan laju penyebaran virus COVID-19, pemerintah sudah membuat kebijakan ialah physical distancing yang antara lain berbentuk kebijakan spesial para partisipan didik diawali dari TK, SD, SMP, SMA hingga PT belajar dari rumah. Pendidik/ guru, guru, siswa, siswa dan orang tua, berhubungan lewat teknologi. Kebijakan ini jadi perihal yang pasti membuat para pendidik buat gencar melatih serta menyesuikan diri terhadap pergantian yang hendak terjalin. Cepatnya penyebaran virus ini serta korban positif yang terus menjadi bertambah membuat Presiden Joko Widodo menetapkan wabah virus Corona COVID- 19 ini bagaikan musibah nasional. Sebagian ketentuan serta kebijakan terus dicoba buat menekan penyebaran serta memutus mata rantai virus ini. Salah satunya dengan pemberlakuan kebijakan social distancing ataupun jarak sosial supaya warga melindungi jarak raga buat melindungi diri dari penyebaran virus. Sejalan dengan perihal tersebut bekerja dari rumah, belajar dari rumah, beribadah dari rumah serta melindungi jarak serta kesehatan diri diberlakukan. Sekolah serta sekolah bagaikan lembaga pembelajaran resmi pasti wajib merespon serta mengambil perilaku hendak suasana ini dengan pas. Kegiatan pendidikan di sekolah serta sekolah di segala Indonesia dihentikan, sebagaimana tertuang dalam Pesan Edaran Mendikbud No 4 Tahun 2020 tentang Penerapan Kebijakan Pembelajaran Dalam Masa Darurat Penyebaran Corona Virus Desease( COVID- 19). Kesehatan lahir serta batin siswa, pendidik serta segala masyarakat sekolah jadi pertimbangan utama penghentian kegiatan pembelajaran di sekolah. 
Kala aktivitas di sekolah" diliburkan", bukan berarti kegiatan belajar tidak dicoba. Mendikbud dengan tegas melaporkan kalau ruang kegiatan belajar dipindahkan dari sekolah ke rumah sehingga proses pendidikan senantiasa berjalan semacam biasa. Salah satu metode dalam pendidikan jarak jauh yang dicoba merupakan dengan mempraktikkan pendidikan daring ataupun online.

Pemanfaatan tekhnologi di masa globalisasi bisa dioptimalkan dalam suasana semacam ini. Sistem pendidikan online berbasis proyek membagikan banyak kesempatan buat mengakses bahan ajar oleh masyarakat pembelajar. Banyak platform ataupun media online yang dapat diakses lewat jaringan internet oleh pengajar ataupun partisipan didik. Sebagian perihal yang jadi hambatan dalam pelaksanaan pendidikan online antara lain kuota internet yang terbatas serta masih belum familiarnya tenaga pendidik beserta partisipan didik dalam mengaplikasikannya.

Pembelajaran daring merupakan pembelajaran "dalam jaringan" sebagai terjemahan dari istilah online yang bermakna tersambung ke dalam jaringan komputer pembelajaran daring (online) sebagai strategi pembelajaran yang menyenangkan bagi pebelajar (siswa) karena dapat menyimaknya dengan melalui smartphone, laptop, maupun komputer bukan hanya sekedar menyimak buku. Pembelajaran daring memiliki beberapa manfaat, di antaranya dapat (1) meningkatkan kadar interaksi pembelajaran antara siswa dengan guru, (2) memungkinkan terjadinya interaksi pembelajaran dimana dan kapan saja, (3) menjangkau siswa dalam cakupan yang luas, dan (4) mempermudah penyempurnaan dan penyimpanan materi pembelajaran. Aktivitas belajar siswa dengan pembelajaran daring (online) dapat membuat siswa tidak merasa bosan, semakin tertarik, dan aktif dalam mengikuti pembelajaran, (5) Kebermaknaan belajar, kemudahan mengakses, dan peningkatan hasil belajar.

Secara berangsur-angsur, banyak organisasi mengadopsi online learning sebagai metode penyampaian utama untuk melatih para pegawai. Meskipun penggunaan sistem belajar online merupakan sesuatu yang mahal dari segi penggunaan paket data, namun dapat ditarik suatu manfaat yang sangat besar dari strategi tersebut baik bagi peserta didik maupun bagi pendidik. Mahalnya pembelajaran online juga masih bisa terjangkau menggantikan biaya transportasi ketika harus datang ke kelas.

Berdasarkan Hasil Penerlitian ada beberapa aspek yang menyebkan motivasi belajar siswa pada masa pembelajaran daring tidak begitu tinggi diantaranya.

\section{Pembelajaran daring masih membingungkan siswa}

Banyak siswa yang mengeluhkan tugas yang banyak tanpa terdapatnya modul yang lumayan sehingga mereka agak kewalahan dalam menjajaki proses pendidikan. Apalagi aplikasi Whatsapp, e- learning, serta pula Zoom masih membingungkan untuk siswa.

Pembelajaran daring memanglah memerlukan menyesuaikan diri serta usaha supaya bisa berjalan mudah. Tidak hanya itu diperlukan usaha buat menguasai modul yang umumnya di informasikan secara lisan jadi tulisan serta video ataupun live streaming. Tetapi sejalan dengan itu terdapatnya sebagian keluhan yang dialami oleh para siswa serta siswa dimana mulai dialami rasa bosan akibat monotonnya tata cara pendidikan.

\section{Informasi atau Materi Pembelajaran Yang Menumpuk}

Berartinya uraian konsep dalam proses belajar- mengajar sangat berengaruh pada perilaku, keputusan, serta caracara membongkar permasalahan, buat itu yang terutama merupakan proses terbentuknya belajar yang bermakna serta proses berpikir untuk siswa. Pada biasanya mereka yang memperoleh pendidikan disekolah acapkali susah buat mempraktikkan pengetahuan yang diperolehnya dengan kasus yang terjalin di dunia nyata, sehingga pengetahuan yang diperolehnya seolah hendak tidak bermanfaat dalam kehidupan tiap hari. Ini merupakan tantangan yang dialami oleh pendidik buat tingkatkan kompetensinya paling utama dalam pendidikan daring ataupun online ini. Perihal ini disebabkan pendidikan daring tidaklah hanya membagikan tugas namun gimana 
pendidikan tersebut bisa bermakna sehingga sanggup membawakan para siswa jadi manusia yang profesional dalam membongkar masalah- masalah dalam kehidupan.

\section{Siswa mengalami stres}

Stress yang dirasakan siswa akibat wabah COVID- 19 ini dipengaruhi oleh keterbatasan buat melaksanakan kegiatan di luar dan kecemasan tertular virus COVID- 19 yang ditunjukkan membagikan cerminan kalau wabah ini memunculkan stress tertentu untuk siswa. Penerapan physical distancing ini pasti memerlukan menyesuaikan diri untuk bermacam pihak. Paling utama untuk siswa yang wajib melaksanakan pendidikan secara daring sejak mewabahnya virus corona.

Kesusahan timbul bukan cuma masalah keahlian pemakaian teknologi, namun pula terpaut dengan beban kerja yang besar mengingat terdapat banyak mata kuliah yang wajib dialami dalam masa pandemi COVID- 19 ini. Perihal ini terjalin sebab siswa terbiasa dengan pendidikan tatap muka secara reguler, sebaliknya pendidikan jarak jauh tadinya cuma dicoba secara insidental. Sehingga pergantian pola pendidikan ini membagikan kasus tertentu untuk siswa. timbulnya tekanan serta tekanan pikiran pada siswa yang melaksanakan pendidikan jarak jauh. Pada titik ini, tekanan pasti jadi terasa lebih berat, sehingga siswa melaksanakan banyak coping stress di mana salah satunya merupakan ikut serta dengan pemakaian media sosial. Jadi pada titik ini, sepatutnya media sosial jadi salah satu jalur keluar meretas rasa bosan maupun tekanan pikiran sebab belajar di rumah. Hanya saja, kondisi jadi berbeda sepanjang pandemi COVID- 19. Kelebihan data sudah teruji menimbulkan social media fatigue sebab membebani kognisi orang.

\section{KESIMPULAN}

Pembelajaran daring masa pandemic Covid-19 mempunyai sebagian akibat terhadap siswa ialah pendidikan daring masih membingungkan siswa; siswa jadi pasif, kurang kreatif serta produktif, penimbunan data/ konsep pada siswa kurang berguna; siswa hadapi stress; dan kenaikan keahlian literasi bahasa siswa. Perihal ini bisa jadi penilaian supaya pendidikan daring bisa diupayakan diterima dengan baik oleh siswa tanpa kurangi esensi pembelajaran itu sendiri.

\section{DAFTAR PUSTAKA}

A.M Sardiman. (2018). Interaksi dan Motivasi Belajar Mengajar. Depok:PT. RajaGrafindo Persada.

Sari MK. Tingkat Stres Mahasiswa S1 Keperawatan Tingkat 19 And Online Lecturer At Karya Husada Health

Oktaviantoro, R. I. (2019). Hubungan Motivasi Dan Disiplin Belajar Dengan Hasil Belajar Ips Siswa Kelas V. Joyful Learning Journal, 6(4), 249-254. https://doi.org/10.15294/ilj.v6i4.16362

Sardiman, A. M. (2012). Interaksi dan Motivasi Belajar Mengajar. PT Raja Garafindo Persada Manuhutu, S. (2015). Analisis Motivasi Belajar Internal Siswa Program Akselerasi Kelas Viii Smp Negeri 6 Ambon. PROMOSI (Jurnal Pendidikan Ekonomi), 3(1), 104-115. https://doi.org/10.24127/ja.v3i1.147

Tim, D. J. P. T. (n.d.). Potret Pendidikan Tinggi Di Masa COVID-19 (T. danNizam Belawan (ed.)). Direktorat Jenderal Pendidikan Tinggi, Kementerian Pendidikan dan Kebudayaan,.

Uno, H. B. (2014). Teori Motivasi dan Pengukurannya: Analisis di Bidang Pendidikan. Bumi Aksara. 